\section{A ALUSÃO A ROMANCES NAS LETRAS PORTUGUESAS DOS SÉCULOS XV-XVII}

\author{
Teresa Araújo \\ Faculdade de Ciências Sociais e Humanas \\ Universidade Nova de Lisboa \\ teresaraujo@fcsh.unl.pt
}

Cómo citar este artículo/Citation: Araújo, T. (2014). "A alusão a romances nas letras portuguesas dos séculos XVXVII". Arbor, 190 (766): a109. doi: http://dx.doi.org/10.3989/ arbor.2014.766n2001

Recibido: 11 septiembre 2012. Aceptado: 16 octubre 2013.

RESUMEN: Las preocupaciones de Ochocientos con respecto al establecimiento de la idea de literatura llevaron al (re)descubrimiento de versos de romances peninsulares en varias obras de autores portugueses contemporáneos de Garcia de Resende, Luís de Camões y D. Francisco Manuel de Melo (incluyendo ellos mismos). Superadas la perspectiva romanticista y la de la filología de la época, así como revisadas las teorías de la intertextualidad de finales del siglo XX, el estudio incide sobre estas interpolaciones en las letras portuguesas. Las interpreta como dispositivos de alusión con efectos musicales, poéticos y semánticos tan diversos cuanto precisos e imprescindibles desde el punto de vista de la economía creativa de las obras que las presentan. A través de la combinatoria identificación de los romances aludidos / interpretación del sentido y función de las incrustaciones deslinda significados textuales que no son perceptibles mediante una lectura meramente lineal.

\section{THE ALLUSION TO ROMANCES IN THE PORTUGUESE LYRICS OF THE $X V-X V I I$}

Copyright: (C) 2014 CSIC. Este es un artículo de acceso abierto distribuido bajo los términos de la licencia Creative Commons Attribution-Non Commercial (by-nc) Spain 3.0.

ABSTRACT: The nineteenth-century concern with establishing the idea of literature led to the (re)discovery of specific verse lines from peninsular ballads in various works of Portuguese authors contemporary with Garcia de Resende, Luís de Camões and Francisco Manuel de Melo (including themselves). With the Romantic perspective and that of the philology of the era now behind us, and having revised the main theories on Intertextuality formulated in the late 20th century, this essay focuses on these interpolations in the Portuguese Literature context. They are interpreted here as allusive devices with musical, poetic and semantic effects as diverse and precise as they are essential from the standpoint of view of the creative poetic paradigm in which they flourished. Through the combinatorial identification between the referred ballads and the interpretation of the meaning and function of the incorporations we are given textual meanings that are not immediately perceived by a first reading. 
Autores portugueses contemporâneos de Garcia de Resende, Luís de Camões e Francisco Manuel de Melo, incluindo os três homens de letras, criaram obras de géneros distintos interpolando hemistíquios e versos de baladas mais ou menos reelaborados por si. Ao incorporarem estas expressões poéticas prévias, instauraram intencionalmente uma relação criativa entre os textos que produziam e os romances aos quais as formas pertenciam para suscitarem efeitos poéticos e semânticos tão diversos quanto precisos e necessários à elaboração das suas obras. Utilizaramnas, portanto, sob formas nem sempre literais e quase invariavelmente como dispositivos de alusão com efeitos múltiplos e imprescindíveis do ponto de vista da economia criativa.

A percepção crítica do fenómeno posterior à sua voga resultou inicialmente das preocupações filológicas oitocentistas de identificação das fontes constitutivas da literatura. No afã característico do século XIX, os eruditos de então detectaram a presença de versos de romances em obras de criação individual e coleccionaram os testemunhos, contribuindo de forma ímpar para a elaboração do catálogo geral de referências. Para o acervo colaborou Ferdinand Wolf, ao dedicar-se às literaturas peninsulares e às suas fontes romancísticas (Wolf, 1856 e Wolf, Hoffmann, 1856); Wilhelm Storck, realçando os vincos tradicionais de certas composições camonianas (Stork, 1885); Teófilo Braga, compilando argumentos para a tese da genuinidade da literatura nacional (Araújo, 2005); concorreu sobretudo Carolina Michaëlis de Vasconcelos, procurando suprir a inexistência de antigas colecções portuguesas de romances (Michaëlis de Vasconcelos, 1885, 1890-1892, 1892, 1897, 1901, 1907-1909).

A filóloga, ao longo dos seus trabalhos, escrutinou meticulosamente os fólios do Cancioneiro Geral de Garcia de Resende (Resende, 1990-2003) e de outras obras publicadas até 1663 e deles extraiu aproximadamente 280 referências feitas por cerca de 50 autores (Di Stefano, 1982, 27). À medida que as apurou, reviu os achados anteriores - como mostram as suas referências a Wolf, Storck, Braga e mesmo a Garrett, embora o subsídio do poeta não tenha sido relevante neste aspecto - e foi dando notícias da sua investigação até a reunir e completar nas páginas da prestigiada revista Cultura española, a convite de Ramón Menéndez Pidal ${ }^{1}$.

Os artigos de Michaëlis de Vasconcelos, compilados posteriormente sob o título Romances Velhos em Portugal (Michaëlis de Vasconcelos, 1980), reflectiram o estado do conhecimento de então sobre o romancei- ro, pelo que exigem atenção crítica. Mas ainda assim continuam a constituir nos nossos dias o inventário de referência dos engastes de versos de baladas nas criações portuguesas deste período e a servir de base e de repto à investigação actual.

As preocupações da filóloga não foram as que surgiram posteriormente e, por isso, pouco ou nada D. Carolina se deteve no significado e na funcionalidade da utilização dos versos das baladas, bem como no papel constitutivo desempenhado pelo procedimento nas obras em que se manifesta. Este novo interesse foi favorecido pelas ulteriores perspectivas da filologia e dos estudos literários em geral, assim como pelo maior conhecimento das tradições antiga e moderna do romanceiro. Beneficiando deste quadro, desenvolveu a combinatória identificação dos temas aludidos / interpretação do sentido e função das interpolações e através da equação deslindou significados textuais que eram imperceptíveis ao leitor comum dos nossos tempos.

A perspectiva surgiu sobretudo a partir da segunda metade do século $\mathrm{XX}$, no contexto dos estudos sobre a poesia cancioneiril e o teatro. Eugenio Asensio terá sido um dos primeiros a articular a identificação dos materiais prévios com a interpretação da sua presença e a conceptualizar o fenómeno como um processo criativo de efeitos estéticos (Asensio, 1957). Outros aprofundaram o filão crítico. Por exemplo, Giuseppe Di Stefano destacou a "stilizzazione" operada por Gil Vicente sobre determinadas formas romancísticas incorporadas pelo dramaturgo (Di Stefano, 1967, 91100). Aida Fernanda Dias realçou a funcionalidade amplificadora das incorporações na lírica portuguesa dos séculos XV e XVI (Dias, 1974, 1978 e 1998). Pere Ferré mostrou que certas interpolações no teatro de Anrique da Mota e de Gil Vicente obedeceram a um processo de parodização das fontes e foram um forte mecanismo de comicidade (Ferré, 1980-1982, 55-67 e 2003, 97-109). E, para não alongar as referências, eu própria analisei este procedimento como dispositivo de humor e por vezes de mordacidade social e política em peças vicentinas, de António Prestes (Araújo, 2004) e de Francisco Manuel de Melo, assim como em textos epistolares de Luís de Camões e nas Lendas da Índia de Gaspar Correia².

Ora, partindo desta tradição crítica dedicada a engastes pontuais e considerando os contributos teóricos que a seguir refiro, proponho agora a revisão da diversidade das interpolações reunidas por D. Carolina como fenómeno essencialmente alusivo, cuja realização obedeceu a uma tipologia de estratégias poéticas 
diversificadas e gerou um quadro preciso de efeitos. Como veremos, embora ele se encontre inscrito nos textos, os versos interpolados remetem sempre (ou quase sempre) para elementos das baladas que extravasam os explícitos.

O dispositivo da alusão literária teve uma das suas primeiras teorizações na influente Agudeza y arte de ingenio, no "Discurso XXXIV" (Gracián, 1669, fols. 221225). Definiu-o Gracián como a "agudeza" que exige não só o conhecimento de textos prévios, mas sobretudo a exímia arte de o aplicar em novos contextos a fim de produzir frutuosas e inesperadas correlações. Observou que a incorporação de um fragmento pode comportar a alteração de uma ou mais palavras e a modificação da própria língua, bem como do significado da referência, sublinhando que estas intervenções favorecem o conceito.

O contributo de Gracián revela-se particularmente luminoso - tendo também em vista o procedimento dos autores portugueses, como veremos -, mas foi sobretudo nas últimas décadas de Novecentos que o recurso alusivo se tornou objecto de reflexão. Nesta altura, a sua teorização assentou em princípios vinculados ao dialogismo bajtiniano e às suas derivações e polémicas bem conhecidas dos anos 60 e imediatos, como registou nos finais do século Joseph Pucci num estudo dedicado à Allusion and Power of the Reader in the Western Literary Tradition (Pucci, 1998). Posteriormente, ultrapassado o extremismo das posições dos primeiros teóricos da intertextualidade, outros pensaram o procedimento criativo e propuseram bases críticas que se afiguram pertinentes também no âmbito dos estudos sobre a relação da literatura individual com os corpora colectivos prévios. Observemos.

"Aludir", etimologicamente "jogar com", neste caso, palavras, consiste num procedimento lúdico - no sentido de ludus proposto a partir de Huizinga (Huizinga, 2004) no âmbito da reflexão filosófica sobre o jogo. Deste ponto de vista, constitui uma actividade organizada por um conjunto de ditames preestabelecidos e reconhecidos pelos intervenientes que instiga à reinvenção mais ou menos surpreendente de relações. Ora foi precisamente a sua qualidade de dispositivo gerador de conexões que mais interessou os últimos teóricos da alusão literária, nomeadamente um dos seus melhores conhecedores, Allan H. Pasco. O professor, depois de recordar a definição clássica de Paul Fontanier, que na verdade coincide com a descrição retórica de Morier (Morier, 1981), “"L'allusion [...] consiste à faire sentir le rapport d'une chose qu'on dit avec une autre qu'on ne dit pas, et dont ce rapport meme reveille l'idee»" (Pasco, 1973, 461), salientou que o fenómeno corresponde a uma articulação entre pelo menos dois termos distintos, gizada e estimulada pelo texto, mas dependente do conhecimento do receptor e da sua competência de síntese interpretativa dos dois elementos. $\mathrm{O}$ conceito, retomado mais tarde pelo mesmo autor em Allusion: A Literary Graft (Pasco, 2002), acentua dois aspectos da alusão que, a meu ver, são cruciais para a inteligência do dispositivo nas obras dos autores portugueses.

Por um lado, o mecanismo encontra-se perfeitamente inscrito no texto. Com efeito, a evocação das baladas ou de alguns dos seus elementos integra estas criações individuais na medida em que hemistíquios e versos do incipit ou de zonas intermédias dos romances surgem plenamente incrustados e articulados no novo texto sob formas mais ou menos adaptadas (como consignava a teorização de Gracián) de acordo com as necessidades linguísticas, semânticas ou poéticas da nova composição. Fazem de tal modo parte do texto que nas primeiras edições das obras - ao contrário de muitas impressões posteriores que, a meu ver, as destacam indevidamente - as expressões de origem romancística nem sequer foram assinaladas graficamente. Apesar de os editores epocais conhecerem muito provavelmente o estatuto de matéria prévia das formas, não as realçaram na impressão, justamente por compreenderem o seu valor constitutivo e a sua natureza de património comum.

Por exemplo, Manuel de Lira editou em 1595 as trovas bilingues camonianas "Disparates seus na Índia" (Camões, 1595, 167v-168v) sem destacar os dois versos de romances que conheceria, pelo menos, a partir da sua edição do Cancionero de romances de 1550 feita em Lisboa, em 15813. Um deles consiste na forma que provém de um dos temas do ciclo de Fernán González, "villas y castillos tengo, todos a mi mandar son" (Cancionero de romances, 1967, 227) e o outro corresponde ao incipit das versões dos Cancionero e demais Romanceiros, não dos folhetos de cordel (Catalán, 1997, 64, nota 112), do romance veIho de cativos, "Mi padre era de Ronda, y mi madre de Antequera" (Cancionero de romances, 167, 284). Também não os assinalou o impressor da importante família de livreiros Crasbeeck (Camões, 1598), como ambos não destacaram a outra expressão romancística engastada nas trovas do poeta, "que se mataran com tres / \& lo mismo haran com quatro" de um dos tema sobre o cerco de Zamora que começa "Riberas de Duero arriba cabalgan dos çamoranos" (Rodríguez 
Moñino, 1997, nos. 31, 663, 736). O primeiro verso, introduziu-o Camões em castelhano, numa estrofe com versos em português e uma expressão em latim, fazendo apenas uma alteração no último vocábulo imposta por necessidade rimática - transformou "son" na forma "sone" para concordar com "bone". O último referido, que surge em segundo lugar nas trovas, não parece ter suscitado qualquer intervenção, pois com excepção da copulativa, o verso é o do folheto de Praga referido (e mesmo esta consta da versão do impresso volante de Madrid). O outro, transformou-o o poeta em discurso indirecto, modificando e aportuguesando a pessoa verbal, também (como o primeiro) por imperativos da nova composição, "que seu padre era de Ronda, / \& su madre de Antequera".

O dispositivo radica no texto também por ser na nova composição que é sintetizada a relação alusiva. Vejamos esta articulação nos "Disparates". O verso do romance épico sobre o conde Fernán González exprime a afirmação pessoal do poder do herói, mas sobretudo a atitude feudal de confronto do nobre vassalo frente ao rei, como é bem explícito na forma romancística anterior a esta, "que yo no he miedo al rey, ni a cuantos con él son", bem como noutros temas do mesmo ciclo, nomeadamente no que relata o seu encontro com Sancho Ordóñez em Carrión (Cancionero de romances, 1967, 227). Interpolado nas trovas camonianas de crítica aos seus contemporâneos que, sendo beneficiados pela fortuna na Índia, "chamão logo al Rey cõpadre" (Camões, 1595, 167v), o seu sentido de origem é parodizado e a alusão resulta numa sátira com alcance não meramente social, de costumes, mas igualmente político, por relacionar em imagem invertida os vínculos nobreza/poder real de contextos históricos tão distintos. O segundo inicia as "palabras de gran soberbia" dos cavaleiros de Zamora, ricamente vestidos e armados, que saem a combater os castelhanos com tanta arrogância quanta cobardia. Engastado na estrofe sobre os portugueses que se vangloriam dos seus feitos bélicos, mas que na guerra "mostrão as costas", reforça a configuração dos contemporâneos do poeta e amplia-a sugerindo que estes nem ao combate saíam. A última expressão baladística de auto-identificação do sujeito do romance dá início ao relato feito pelo próprio do seu cativeiro entre mouros, no qual descreve as suas desventuras enquanto escravo. Incorporado na estrofe dedicada aos que pretendem fazer-se passar pelo que não são, ao "rafeyro velho / que se quer vender por galgo", evoca em imagem invertida com notório efeito hilariante e mordaz a vítima do romance, associa parodicamente o cristão vertido em escravo ao farsante indigente.
Por outro lado, como vimos Allan Pasco sugerir, o dispositivo assenta igualmente na competência do receptor. Os autores dos séculos XV-XVII utilizaramno porque sabiam poder contar com a capacidade de "leitura literária" do seu público, para usar a expressão de Rifaterre (Rifaterre, 1979, 163) convergente com a noção de intertextualidade de Laurent Jenny (Jenny, 1979, 5), utilizadas geralmente no âmbito do universo literário dominado pelo escrito. No período em apreço, a recepção literária decorreu frequentemente num contexto de transmissão oral, em pequenas comunidades, tendo sido menos comum a leitura individual e solitária, como sublinharam entre outros Margit Frenk (Frenk, 1982, 101-123) e Ricardo Senabre (Senabre, 1991, 194), mas o processo hermenêutico não terá sido diferente. Aliás, a circunstância tê-lo-á até favorecido: como os romances aludidos faziam parte do acervo memorial colectivo, pelo menos do que era comum aos letrados de então (apreendido pela audição ou leitura dos impressos romancísticos e pelo canto), a percepção das suas formas e a sua interpretação nas novas composições terá sido mais frutuosa nesta partilha, nesta comunidade. O público, desfrutando das criações dos seus contemporâneos ou dos autores que continuavam a despertar o seu interesse, detectava as expressões prévias mais ou menos manipuladas do ponto de vista discursivo e semântico e logo entendia o seu significado e a sua funcionalidade no novo contexto. Ou seja, compreendia a relação dialéctica dos dois termos, o romance e a nova composição, porque era capaz de fazer uma interpretação não meramente linear da obra. O processo torna-se mais claro à luz das etapas estabelecidas por Plett no contexto da sua teorização sobre a recepção intertextual (Plett, $1993,79)$. Vejamos: num primeiro momento, os que liam ou escutavam a nova composição interrompiam o contínuo da interpretação face ao reconhecimento de uma forma prévia guardada na sua memória; logo a compreendiam por anamnese do romance de origem e imediatamente a integravam com as devidas alterações na linearidade da percepção da obra. Encontrava-se assim garantido o sucesso funcional do dispositivo e a eficácia da estratégia criativa.

Como observámos nos "Disparates", os autores portugueses, ao recorrerem a versos da abertura dos romances e de zonas intermédias - na verdade, mais destas do que do incipit, como também notou Giuseppe Di Stefano (Di Stefano, 1982, 31-32) - para aludirem a determinados elementos das baladas, intervieram frequentemente nas formas que engastavam. Com efeito, várias interpolações não são transcrições 
literais das expressões poéticas antigas que conhecemos, nem muito provavelmente das que soavam nas vozes da época, uma vez que a memória colectiva actual não as conservou. Assim, mesmo admitindo que algumas possam corresponder (como veremos) a uma lição que não mereceu letra impressa nem a conservação memorial e pelo canto através dos séculos, a grande parte das divergências nasceu no laboratório criativo dos autores devido a imperativos de adaptação das formas prévias ao novo contexto literário. Vejamos os principais traços desta poética gerada pelas necessidades formais e semânticas do novo contexto e da intencionalidade significativa do autor.

A língua predominante do artifício alusivo foi a dos romances fixados pelas primeiras edições das baladas, a qual, como é sabido, era bastante familiar aos letrados portugueses e usada frequentemente no seu trabalho criativo. No entanto, apesar da preponderância do castelhano (em boa verdade, com muitos lusismos), o idioma dos autores e público foi utilizado, quer parcialmente através da substituição de alguns vocábulos, quer de forma integral, trajando todo o verso.

A maior parte dos casos de ocorrência mínima do português não terá resultado da iniciativa autoral, mas de vicissitudes tipográficas, uma vez que a desarmonia linguística não apresenta, salvo uma ou outra excepção, qualquer significado poético, semântico ou funcional. Assim terá sucedido com o engaste vicentino do hemistíquio "Ios hijos de doña Sancha" (Obras de Gil Vicente, 1928, fol. LVv) do romance sobre a querela de doña Lambra (Cancionero de romances, 1945, fol. 163v): sem que se entreveja qualquer justificação, surge com o título honorífico feminino em português.

As interpolações totalmente em português devem ter sido, em princípio, da lavra dos autores, do seu trabalho de tradução, mas alguma delas pode reflectir os prenúncios da tradição nesta língua. Penso que um exemplo deste fenómeno minoritário reside no engaste de "Passeava-se Silvana / por um corredor um dia" n' O Fidalgo Aprendiz (Melo, 2007, 145), uma vez que a forma poética, embora não tenha sido fixada pelos impressores antigos, é uma das de abertura mais frequente de "Silvana" (Ferré, 2000-2004, III, 324-340) e de poemas contaminados por este romance, nomeadamente um conjunto de versões do "Conde Alarcos" (Ferré, 2000-2004, II, 332-490)4. Mas suponho que a generalidade manifesta o burilar linguístico dos autores, até por incluir frequentemente outro tipo de intervenções criativas, sendo menos comuns os casos de tradução literal do verso romancístico, como o da interpolação presente no "Memorial a El Rei nosso Senhor D. João, o quarto" de Francisco Manuel de Melo (Melo, 2006, 713-714). O poeta, para salientar o abandono da propriedade para a qual chamava a atenção do monarca, introduziu a fórmula "de ũa parte a cerca o Douro, / da outra penha talhada" que é a versão portuguesa literal da descrição elogiosa de Zamora feita pelo rei Fernando frente às reivindicações sucessórias de sua filha Urraca, "de una parte la cerca el Duero, de otra peña tajada" (Cancionero de romances, 1967, 213).

Em qualquer caso, a utilização das duas línguas não distinguiu autores ou períodos no arco temporal dos séculos $\mathrm{XV}$-XVII, ao ponto de ambas figurarem por vezes no mesmo fragmento, como sucede na alusão de António Prestes a um dos romances sobre a perda de Alhama pelos mouros, "Moro alcayde, moro alcayde, el de la barva vellida" (Cancionero de romances, 1967, 248). O dramaturgo, incrustando este incipit e uma forma presente em hemistíquios subsequentes, "porque Alhama era perdida" e "porque es Alhama perdida", impregnou a fala da personagem Sensualidade dirigida ao Diabo do sentido de admoestação dos dois primeiros versos da balada e das nefastas consequências que o seu interlocutor colheria se não a introduzisse no castelo do seu pretendido Cavaleiro:

Moro alcaide, moro alcaide

el de la barba vellida

$s^{\prime}$ eu por vos não for metida

$\mathrm{n}^{\prime}$ el castillo de Belsayde

dou Alfama por perdida

(Autos de Prestes, "Auto da Ave-Maria", 2008, 79).

O incipit em castelhano no início da fala da personagem de um auto predominantemente em português, consiste numa estratégia de captatio benevolentiae do público conhecedor de romances para sublinhar o estatuto subtextual da expressão e a consequente comparação em imagem invertida do Diabo e do mouro que de certo modo foi vítima da perda de Alhama. Lançado o jogo alusivo, o seu final foi realizado na língua em que a figura profere sempre as suas alocuções.

Mas independentemente da língua usada, os autores intervieram mais ou menos profundamente nas expressões que utilizaram. Frequentemente, restringiram-se à adaptação de elementos mínimos, como o já observado da alteração da pessoa verbal. Mas, como veremos de seguida em dois casos em portu- 
guês e dois em castelhano, também desenvolveram liberdades criativas sobretudo alterando a ordem de constituintes dos versos, articulando hemistíquios não sequenciais, assim como desmembrando e recompondo parcialmente fórmulas romancísticas com versos de invenção própria, para além de terem recriado, sobretudo os últimos cultores do artifício, alguns versos em formas que modificam inclusivamente o sentido das expressões prévias, recorrendo contudo ao seu significado.

Uma composição de sátira e folgar de Pedro de Almeida bem representativa do riso mordaz, por vezes insultuoso (Dias, 1998, 360), do Cancioneiro Geral exemplifica o primeiro procedimento. Refiro-me ao poema de ridicularização da rapidez com que João Rodrigues de Sá substituiu o seu barrete por uma carapuça de veludo, cedendo à crítica de Dona Ana d'Eça a quem dedicava em vão certas preferências (Resende, 1990, II, 444-445). Termina, dizendo: "S'o barrete bem volava, / la egua mijor corria".

A expressão poética não tem paralelo directo nas antigas versões impressas dos romances, embora os poemas quinhentistas da balada sobre o repto de Búcar a Valência e a célere fuga do mouro à veloz perseguição de Cid incluam dois versos que visualizam o dinamismo do encalço através do movimento das montadas dos cavaleiros. A glosa de Francisco de Lora contempla "Do la yegua pone el pie Bavieca pone la pata" (Catalán, 1969, 147148) e o Cancionero s.a., para além desta forma, "la yegua, que era ligera, muy adelante passava" (Cancionero de romances, 1945, 179r). Os versos de Pedro de Almeida podem ter sido uma recriação profunda destes com a deslocação e tradução do vocábulo "yegua" do primeiro para o segundo termo da expressão, o que consistiria numa alusão mordaz à senhora.

Mas é possível que reflictam a reelaboração da forma de uma versão não impressa da balada, cuja existência foi admitida por Diego Catalán (Catalán, $1969,150)$, pois encontram relação noutras ocorrências distintas. Por um lado, têm semelhança com o verso incrustado em Ulyssipo, "Se o cavalo bem corria a egua melhor voava" (Vasconcelos, 1618, fol. 155). Por outro, têm-na com uma expressão poética do romance recolhida no século $X X$, em diferentes trabalhos de campo, numa das áreas mais conservadoras da tradição moderna portuguesa, Bragança: "se a Babeca corre muito, o meu cavalo voava" (Tavares Teixeira, 1906, 306; Martins, 1928/1987, 233, reimpressas in Ferré, 2000-2004, I, 160-162).
Neste caso, a alteração de Pedro de Almeida foi outra, consistiu na inversão da ordem dos verbos. Quer a forma poética de Jorge Ferreira de Vasconcelos, quer as transmontanas, tal como a do poeta do Cancioneiro Geral, fazem referência à égua na segunda parte da expressão, mas apenas a deste poeta antepõe "voar" a "correr". Assim, tenha ele recriado a partir das formas de Francisco de Lora e Martin Nucio ou da hipotética versão que desconhecemos directamente na tradição antiga, procedeu a uma modificação da sequência poética prévia, para além de ter substituído o nome do cavalo Babieca por "barrete" (palavras foneticamente próximas) - aspecto que não apoia a possibilidade de o poeta ter aludido à forma registada pelo seiscentista Gonzalo Correas como proverbial, "Si el caballo bien corría, la yegua mejor volaba" (Correas, 1992, 451). Através desta recriação, o poeta provocou seguramente o riso no público conhecedor do romance e introduziu uma alusão de forte efeito jocoso. Associou as atitudes dos visados ao desempenho quinhentista das alimárias dos cavaleiros medievais - de Babieca do ardiloso Cid e da égua do mouro covarde.

Observa-se o artifício criativo da justaposição de hemistíquios não sequenciais, por exemplo, na Comedia de Rubena, quando Benita aludiu ao romance que circulava na imprensa do século XVI em diferentes versões, mas sempre com a abertura "Tiempo es, el cavallero, tiempo es de andar de aquí" ou "... de ir de aquí"). Benita entoa na peça "Tiempo era cavallero / que se m' acorta el vestir" (Vicente, 1924, fol. LXXXVIIIv.). A primeira parte coincide com o hemistíquio inicial do romance sobre o fruto dos amores ilícitos de uma donzela com um cavaleiro e a segunda corresponde ao quarto da mesma balada, por exemplo, na versão de um folheto de Praga, integrado no verso "que me cresce la barriga e se me acorta el vestir" (Pliegos de Praga, 1960, II, LXXVI, 281). O público compreendeu imediatamente a intencionalidade da alusão de Benita ao romance: a de afirmar o conhecimento que tinha dos dissimulados favores amorosos de Rubena a um jovem clérigo e da gravidez da sua senhora, assim como a de associar a mordacidade da criada ao riso das donzelas do romance. Mas porque articulou Gil Vicente diferentes hemistíquios, criando uma expressão poética em si mesmo enigmática? Se atendermos à cena em que ela decorre, logo a recriação revela a sua acuidade formal e semântica. O diálogo entre as duas figuras é um debate de entreditos, no qual a criada sugere implicitamente o estado da senhora e esta dissimula-o com diagnósticos diversos e com o pedido da presença de Genebra para a "bendezir / del quebranto" (Vicente, 1924, fol. LXXXVIIIv.). 
A invenção vicentina composta pela articulação dos dois hemistíquios separados por dois suprimidos, que completam o sentido dos utilizados, constitui o xeque-mate subentendido do jogo de simulação e entreditos em que ela própria colabora com intencionalidade cómica e crítica.

O terceiro procedimento, a fragmentação de uma expressão prévia e a sua recomposição parcial com novos versos, encontra-se, entre outros casos, no final das trovas que João Rodrigues de Sá dirigiu à sua senhora para provar a intensidade da sua paixão e contradizer os "motos" enviados por casteIhanos à sua dama (Resende, 1990: 434-440). Termina a composição invocando directamente estes senhores:

$$
\begin{aligned}
& \text { Agora depois d' achar } \\
& \text { em meus erros o que neles } \\
& \text { nom podês dissimular, } \\
& \text { nisto m' havês de salvar: } \\
& \text { em serem próprios aqueles } \\
& \text { que sam pera perdonar. }
\end{aligned}
$$

A referência do poeta do Cancioneiro Geral pode ter sido a expressão autonomizada que no século XVII foi acolhida no Vocabulario de refranes y frases proverbiales, em duas modalidades, "Los yerros por amor dinos son de perdonar" e "Yerros de amor dinos son de perdón" (Correas, 278 e 514). Mas atendendo a um aspecto contextual e a outro extracontextual da alusão, inclino-me a considerar que ela visava o romance com grande fortuna editorial no século XVI, "Media noche era por filo, los gallos quieren cantar" ou "... querian cantar" (vide, por exemplo, Pliegos de Praga, 1960, I, folh. V, 33 e Cancionero de romances, 1945, fol. 83-90, respectivamente).

A interpolação surge num poema em que o sujeito, ao proclamar o seu amor como desígnio vital da sua existência e os favores da senhora como galardão pessoal, apresenta a configuração cancioneiril da figura de Conde Claros, bem expressa no pedido que o amante da balada faz ao pajem, quando espera no cárcere a execução da sentença por ter privado intimamente com a princesa:

- Por Dios te ruego, el paje, en amor de caridad, que vayas a la princesa de mi parte a le rogar que suplico a su alteza que ella me salga a mirar, que en la hora de mi muerte yo la pueda contemplar, que si mis ojos la veen la muerte no me penará

(Pliegos de Praga, 1960, I, folh. V, 33).

Por outro lado, todos os engastes portugueses da forma - com excepção talvez da que se encontra na Menina e Moça (Michaëlis de Vasconcelos, 1980, 155158) - aludem ao verso do romance, desde os do Auto do Procurador, do Auto de Rodrigo e Mendo, ao de Ulyssipo, ao do camoniano El Rei Seleuco e ao da composição seiscentista de D. Francisco de Portugal que apresentarei em último lugar. Claro que nenhum dos dois argumentos nega a possibilidade de Rodrigues de Sá ter mencionado as frases proverbiais de Gonzalo Correas, mas a sua articulação leva-me a considerar muito provável a alusão ao romance.

$\mathrm{Na}$ versão da balada de um folheto de Praga, a expressão é proferida por duas vezes (com uma pequena variação) pelo arcebispo quando este visita o sobrinho, Conde Claros, no cárcere e Ihe manifesta compreensão pelo delito:

- Pésame de vos, el conde, cuanto me pode pesar,

que los yerros con amores dignos son de perdonar.

De vos me pesa, el buen conde, porque assí os quieren tratar, que los yerros que heziste dignos son de perdonar.

(Pliegos de Praga, 1960, I, folh. V, 33)

Admitindo que João Rodrigues de Sá pretendeu aludir à benevolência do clérigo e através dela à figura de amante cancioneiril, o poeta cindiu a fórmula romancística e reelaborou-a parcialmente com a integração de versos próprios (que invocam o motivo dos erros e o utilizam como argumento de benevolência), para expor um contraditório com o recurso à auctoritas da expressão poética prévia proferida pelo arcebispo e reiterar a sua profissão amorosa. A recriação, ao contrário das anteriores, é desenvolvida em contexto sério, mas a alusão suscita igualmente fortes efeitos.

Finalmente, consideremos a reelaboração desta última expressão romancística sob a mão de D. Francisco de Portugal, para observarmos um exemplo de intervenção poética que altera em todos os planos a forma prévia recorrendo contudo à sua referência. A expressão surge no "Romance XVI" (Portugal, 1652, 74-75), que se constituiu a partir não da parcimoniosa utilização do artifício, como se verifica suceder anteriormente a este período, mas da exuberância da estratégia que, neste fulgor, é bem representativa do seu esgotamento e da enorme voga do Romanceiro Novo. Aparece integrada numa longa cadeia de alusões a diferentes 
baladas (a qual exige naturalmente estudo próprio) e na zona intermédia de uma série de outras referências a "Conde Claros". Vejamo-la no contexto do fragmento relacionado com este romance.

Depois de o poema desenvolver um conjunto de advertências e considerações em torno da inconstância amorosa dirigidas ao pensamento autonomizado do sujeito que parte em direcção à dona mobile, diz o seguinte ao seu destinatário:

De muger prendada, y noble

quien no havia de confiar?

Bolóos, mintió y dexóos

qual si fuera gavilán.

Divertida en otros gustos

que hermosa, y falsa estará!

Sin que en cosa vuestra piense

de placer, o de pesar.

Tan grandes facilidades

ningún sagrado hallarán:

que yerros son solo en amores

indignos de perdonar.

[...]

Muerto en mudanças os lloro

de vós cien mil veces ay!

Conde Claros de firmezas,

Como podeis reposar?

$\mathrm{O}$ verso que associa a senhora à ave altera o discurso do segundo hemistíquio da fórmula "salto diera de la cama que parece un gavilán" (Cancionero de romances, 1945, fol. 83-90) por uma equivalente, mas transfere o frémito erótico do Conde para a figura feminina. Modificado, explica a causa e caracteriza depreciativamente o comportamento da senhora, assim como implicitamente isenta o amante preterido da responsabilidade pela mudança da senhora. $O$ público de então, conhecedor do tema, não terá repudiado o deslocamento criativo, uma vez que também recordava a disposição erótica da donzela da balada,

mas dexame ir alos baños alos baños a bañar

cuando yo sea bañada estoy a vuestro mandar.

Compreendeu que ele decorria da perspectiva do novo contexto e percepcionou o seu significado na nova composição, assim como percebeu a alusão ao verso sobre os erros por amor profundamente recriada do ponto de vista discursivo e semântico. A introdução do advérbio de exclusão ("solo") e do prefixo negativo ("indignos") elevam os devaneios femininos à máxima imoralidade e retira-os do alcance da magnanimidade transcendente e humana, segundo o título da obra que acolhe o poema, Divinos e Humanos Versos. O último engaste da série, que relaciona surpreendentemente o amante com o Conde, também é realizado através de dois procedimentos linguísticos com significativo efeito. A substituição do vocábulo "amores" da expressão prévia, "conde claros con amores no podia reposar", por "firmezas", faz recair sobre o persistente amante a intensidade da inquietação erótica da figura da balada. Ao mesmo tempo, a transformação do verso em forma interrogativa acentua a angústia do que não é correspondido na sua constância amorosa.

Os quatro modos de intervenção autoral mais profunda exemplifiquei-os com três interpolações em contexto lírico e uma em situação dramática, sem indicar engastes provenientes de textos em prosa, historiográficos, epistolares ou outros. A amostragem parece anómala depois de ter afirmado a generalidade do fenómeno alusivo, mas nem a desproporção entre as primeiras e a segunda reflecte a distinta preferência dos dois géneros pelo romanceiro, nem a falta de engastes em obras em prosa decorre da inexistência de versos de baladas neste tipo de textos. A assimetria entre as incorporações na lírica e no teatro corresponde à distinta incidência do fenómeno de manipulação discursiva nos dois géneros, que competem entre si quase em paridade na utilização alusiva das baladas (embora o teatro com ligeira vantagem). A ausência dos últimos advém do desequilíbrio destes face aos anteriores, mas deriva sobretudo da escassez de recriação dos engastes alusivos ao nível da linguagem. Nos géneros em prosa, a evocação é quase sempre realizada mediante a incrustação quase literal dos versos, sendo o novo contexto que dita a reconfiguração do sentido do subtexto - aliás como frequentemente no teatro.

A intervenção dos dramaturgos nos versos de origem é bem mais expressiva (como vimos e mostram os estudos monográficos citados), mas também não é proeminente. Como estes autores os utilizaram sobretudo nas suas obras de temática cómica e preferiram expressões de romances épico-históricos e clássicos, a introdução de formas poéticas pouco manipuladas foi artifício bastante e eficaz para gerar efeitos burlescos 
e jocosos, pelo contraste que instaurava. Quando porém recorreram a versos de baladas novelescas, geralmente recriaram-nos de forma exímia no sentido de suscitarem ressonâncias semânticas e poéticas, como verificámos no último exemplo vicentino.

Os líricos submeteram os materiais prévios a maior reinvenção criativa pela necessidade de adaptarem fórmulas de um género de linguagem substantivada (embora, como se sabe, essencialmente figurativa) a um contexto de tonalidade emocional, algumas vezes cómica, outras séria. Porém, nos casos em que utilizaram versos épico-históricos com intencionalidade crítica e de riso, também pouco ou nada os alteraram pelo mesmo motivo que os dramaturgos quase não os reelaboraram, segundo vimos nos "Disparates" camonianos e no poema de Francisco Manuel de Melo dirigido a D. João IV - apesar de surgirem casos como o de Pedro de Almeida.

No seu conjunto, as interpolações alusivas referidas ilustram os grandes vectores da diversidade funcional da estratégia. Revelam a utilização paródica com finalidades de crítica jocosa e de sátira de alcance social, militar e político (caso dos “Disparates seus na Índia”), assim como o uso em contexto sério com a intenção de intensificar conteúdos de índole emocional. Boa parte delas exemplifica a função estruturante da alusão romancística na construção de cenas dramáticas (como a da Comédia de Rubena), de composições líricas (recorde-se a de D. Francisco de Portugal), ou de figuras, como Rubena, o sujeito do poema de João Rodrigues de Sá e a inconstante senhora de D. Francisco de Portugal. Algumas demonstram que, no teatro, tanto surgiram integradas no discurso das personagens para impregnar as alocuções de ressonâncias semânticas geralmente hilariantes (lembremos a de Sensualidade), como introduziram momentos musicais com efeitos não meramente estéticos, segundo se observou na Comédia de Rubena. Outras ainda reflectem que o artifício alusivo acumulou outras funções retóricas e argumentativas, nomeadamente a captatio benevolenciae (especialmente o de António Prestes) e a auctoritas (em particular, o do poeta humanista João Rodrigues de Sá).

Abeiramo-nos assim da pergunta final sobre o enquadramento poético e ideológico da alusão a romances. O procedimento reflectiu a persistência do recurso medieval a textos prévios memoriais. Como os seus antecessores, os letrados quinhentistas continuaram a utilizar criativamente os corpora partilhados com gente menos instruída, como alegou, por exemplo, Maxime Chevalier, ao justificar a presença de contos tradicionais em diversas obras de autoria individual (Chevalier, 1995, 116-117).

Mas porque recorreram estes criadores de uma profunda renovação cultural a narrativas poéticas consideradas por si próprios histórias em verso muito antigas? Autores como Jorge Ferreira de Vasconcelos e Diogo do Couto manifestaram plena consciência do arcaísmo dos cantos a que aludiam, designando-os explicitamente por "Romances Velhos". Em certa medida, a coexistência do velho e do novo neste período de inovações terá favorecido a conservação do artifício, no entanto o vigor do recurso aponta para novos vectores ideológicos e poéticos.

Por um lado, como bem salientou Margit Frenk na linha de Américo Castro (Frenk, 1997, 2006), o interesse e gosto erudito renascentista pelos géneros tradicionais e a utilização (essencialmente aristocrática) do legado medieval, tido então por avoengo, correspondeu a um movimento semelhante ao da voga da literatura pastoril, repleta de pastores elegantemente rústicos. Obedeceu à idealização epocal, de base neoplatónica, do primitivo e do natural e à consequente valorização de tudo quanto, para a inteligência quinhentista, reservava manifestações do primordial, livre dos vícios civilizacionais. A descoberta do Novo Mundo, como se sabe, favoreceu o aparecimento de mitos como o da "Idade de Ouro" e do "Bom selvagem" e logicamente, como realçou a especialista, "el aprecio por los brotes del ingenio y la fantasía del vulgo (refranes, cantares, juegos infantiles). Toda Europa pasa entonces por esa misma experiencia vital" (Frenk, 1997, 16).

Com efeito, muitos autores portugueses manifestaram expressamente o gosto pelas antigas histórias em verso mais ou menos verídicas e com sabor agradável pela sua simplicidade.

Jorge Ferreira de Vasconcelos, há pouco referido, deu eco, na sua Comedia Eufrosina, às palavras de Martin Nucio retomadas por Esteban de Nájera, sobre o apreço geral pelas baladas. Escreveu o impressor de Antuérpia, a propósito do seu Cancionero de romances, "cualquiera persona para su recreación y pasatiempo holgaría de lo tener, porque la diversidad de historias que hay en él dichas en metros y con mucha brevedad será a todos agradable" (Cancionero de romances, 1967). O editor de Zaragoza, pouco depois, utilizou a mesma expressão, serem agradáveis a "cualquier persona para su recreación y pasatiempo" (Silva de romances, 1970, 47). Por seu lado. o dramaturgo português, disse-o através do cortesão Zelótipo quando aconselhou bons modelos poéticos a Cariofilo e 
destacou os "Romances Velhos, que sam apraziveis" (Vasconcelos, 1560, 173). Como se sabe, neste mesmo fragmento dramático, Zelótipo critica o caudal de glosas de baladas saídas das mãos de poetastros, mas a referência servia sobretudo para desclassificar a habilidade poética do escudeiro, igualando-a à dos versejadores populares que, diz o cortesão aludindo ao local de muitas publicações de romances e glosas, assim ganhavam as suas migalhas montando "tenda em Medina del Campo" (ibidem).

Também o sucessor de João de Barros e guardadormor da Torre do Tombo de Goa deixou vários testemunhos deste apreço (Couto, 1780). Vale a pena ler um deles, por manifestar a consciência da antiguidade e valia das narrações poéticas, mas também por exemplificar a competência epocal de leitura do artifício alusivo que expus anteriormente. $\mathrm{O}$ fragmento surge depois da referência a uma falsa notícia sobre o pagamento, feito pelo vice-rei D. Constantino de Bragança, de uma nau mandada construir por si para regressar a Lisboa, utilizando o erário real. Diz assim:

E tanto, que lhe contrafizeram aquelle Romance VeIho que diz: Mira Nero de Tarpea a Roma como se ardia em Mira Nero da janella la nave como se hazia. No que não tiveram razão, porque nem a elle lhe cabia tal nome, por ser muito alheio, e differente da sua natureza, nem a sua náo foi feita com encargos com que outras depois se fizeram por alguns Capitães, nem com os aparelhos e madeiras das ribeiras de ElRey" (Couto, 1783, 433).

Diogo do Couto alongou-se na defesa de D. Constantino, mas como se observa exprimiu consideração por aqueles poemas velhos, nomeadamente pelo romance que já fora cantado por Sempronio a Calisto (Díaz-Mas, 2006, 376) e circulava também em folheto (Rdríguez Moñino, 1997, nㅇs. 629, 664.5, 870 e 1077), distinguindo-o da paródia feita pelos seus contemporâneos. Além disso, como dizia, o historiógrafo expôs claramente a leitura da alusão jocosa, ou seja, da re- lação criada entre o vice-rei e a figura de Nero com intenção de associar quem teria delapidado a coroa a quem tinha destruído a cidade imperial.

Não obstante estes exemplos e outros que poderia trazer à colação, o recurso a romances correspondeu também, num número de casos não menos despiciendo, ao progressivo movimento de des-idealização do universo cavalheiresco de onde provinham os materiais poéticos que se manifestou, como lembrava Pere Ferré, na Celestina e no Lazarillo (Ferré, 2003, 97-98), assim como, acrescentemos, no Don Quijote de la Mancha. Segundo se observou em muitas interpolações, a utilização alusiva das baladas foi frequentemente paródica, reconfigurando em imagem invertida personagens e temas medievais. Ora, que representará esta estratégia criativa senão a profunda reformulação conceptual do legado e a nova ideologia renascentista?

O artifício prolongou-se, como vimos, por Seiscentos, como aliás a utilização de outros materiais de base tradicional, como mostrou recentemente Pedro Serra no seu estudo sobre a interpolação de provérbios na obra de D. Francisco Manuel de Melo (Serra, 2003, 61-71). O intencional alargamento das letras à burguesia urbana, em boa medida proveniente de meios rústicos, levou os poetas e dramaturgos a integrarem, nas suas criações, materiais conservados pelo vulgo e a articularem-nos com os eruditos - um procedimento bem conhecido da máquina poética barroca de produção de contradições. No entanto, a estratégia alusiva a romances foi cedendo nesta altura ao seu próprio esgotamento e dando passo à voga de um tipo de composições que era cada vez menos parecido com os poemas conservados pela memória e cada vez mais brunido pelas agudezas e conceitos engenhosos (Frenk, 2006, 77-78). Será necessário esperar pelo século XIX para os homens de letras redescobrirem o género e utilizarem-no como matéria criativa. 
1 Vide a "Advertência Preliminar» escrita em Dezembro de 1909 que abre a colecção dos artigos publicada inicialmente em 1934 e depois em 1980 (página sem numeração).

2 “Alusões Epistolares Camonianas ao Romanceiro Velho", in Manuel Calderón (org.), Homenagem Stephen Reckert, Lisboa, Imprensa Nacional - Casa da Moeda (no prelo) e Romances de tradição antiga: o género e as suas manifestações em Portugal [Relatório referente ao seminário Problemas de Literatura Tradicional (Curso de Mestrado em Estudos Portugueses) apresentado no âmbito das provas para acesso ao título de Agregada no Ramo de Estudos Portugueses, Especialidade em Literatura Tradicional e Oral], Lisboa, Universidade Nova de Lisboa, p. 81.

3 O livreiro português apenas suprimiu as duas versões finais da colecção de Antuérpia, segundo a descrição que Rodríguez Moñino fez desta edição hoje mui- to rara. Não incluiu "Llanto haze el rey David" e "Con ravia esta el rey David" (Rodríguez Moñino, 1973: I, 221-222).

4 Noutro local, procedi ao estudo desta alusão de Francisco Manuel de Melo: "Entreditos da Corte Amorosa de Dom Gil", in Mundo é Comédia. Actas do Congresso Internacional D. Francisco Manuel de Melo - Mundo é Comédia, Faculdade de Ciências Sociais e Humanas da Universidade Nova de Lisboa, 1-3 de Abril de 2009 (no prelo).

\section{BIBLIOGRAFÍA}

Araújo, Teresa (2004): “O sentido de algumas evocações vicentinas a romances velhos" e "Memórias literárias portuguesas de romances sobre a perda de Alhama", in Portugal e Espanha: Diálogos e Reflexos Literários, Faro, Lisboa, Centro de Estudos Linguísticos e Literários, Instituto de Estudos Sobre o Romanceiro Velho e Tradicional, pp. 11-65 e 67-91.

Araújo, Teresa (2005): “Um Esboço dos "Romances Velhos em Portugal»", in Rafael Alemany, Josep Lluís Martos i Josep Miquel Manzanaro (coord.), Actes del $X$ Congrés Internacional de I'Asociació Hispànica de la Literatura Medieval, Alicante, Symposia Philologica, pp. 283-293.

Asensio, Eugenio (1957): Poética y realidad en el cancionero peninsular de la Edad Media, Madrid, Gredos (2ª. ed., 1970).

Autos de Prestes (2008): Autos de António Prestes, edição de José Camões e de Helena Reis Silva com "Introdução" de José Camões, Lisboa, Imprensa Nacional - Casa da Moeda.

Camões, Luís (1595): Rhythmas de Lvis de Camoes diuididas em cinco partes, Em Lisboa, Por Manoel de Lyra.

Camões, Luís (1598): Rimas de Lvis de Camoes, accrescentadas nesta segunda impressão..... Em Lisboa, Por Pedro Crasbeeck.

Cancionero de Romances (1945): Cancionero de romances, edición facsímil y estudio de Ramón Menéndez Pidal, Madrid, CSIC (1a. ed., Anvers, Martín Nucio, s.a.).
Cancionero de Romances (1967): Cancionero de romances, edición y estudio de Antonio Rodríguez Moñino, Madrid, Castalia (1a. ed., Anvers, Martín Nucio, 1550)

Catalán, Diego (1969): Siete siglos de Romancero (Historia y poesía), Madrid, Gredos.

Catalán, Diego (1997): Arte poética del romancero oral, Parte 1a., Los textos abiertos de creación colectiva, Madrid, Siglo Veinteiuno de España Editores.

Chevalier, Máxime (1995): “Cuento tradicional y literatura del Siglo de Oro", in José María Díaz Borque (dir.), Culturas en la Edad de Oro, Madrid, Editorial Complutense, pp. 113-121.

Correas, Gonzalo (1992): Vocabulario de refranes y frases proverbiales y otras fórmulas comunes de la lengua castellana en que van todos los impresos antes y otra gran copia, prólogo de $\mathrm{Mi}$ guel Mir y edición de Victor Infantes, Madrid, Visor Libros.

Couto, Diogo do (1780): da Asia de Diogo do Couto. Dos feitos, que os Portuguezes fizeram na Conquista, e Descubrimento das Terras, e Mares do Oriente. Decada Setima. Parte Segunda, Lisboa, Na Regia Officina Typographica.

Di Stefano, Giuseppe (1967): “Popolarismo e stilizzazione: il sarto gradazo di Gil Vicente" in Sincronia e diacronia nel Romancero (un esempio de lettura), Pisa, Università di Pisa, pp. 91-100.
Di Stefano, Giuseppe (1982): “II romancero viejo in Portugallo nei secoli XV-XVII (Rileggendo C. Michaëlis de Vasconcelos)", Quaderni portoghesi, 11-12, pp. 27-37.

Dias, Aida Fernanda (1974): Motos, vilancetes, cantigas e romances glosados, Separata da Revista de História Literária de Portugal, III, Coimbra, Faculdade de Letras da Universidade de Coimbra.

Dias, Aida Fernanda (1978): O Cancioneiro Geral e a Poesia Peninsular de Quatrocentos. Contactos e Sobrevivência, Coimbra, Livraria Almedina.

Dias, Aida Fernanda (1998): "A Temática" in Garcia de Resende, Cancioneiro Geral de Garcia de Resende, fixação do texto e estudo por Aida Fernandes Dias, V, Lisboa, Imprensa Nacional - Casa da Moeda, pp. 109-402.

Díaz-Mas, Paloma (2006): Romancero, Barcelona, Crítica (1a. ed., 2001).

Ferré, Pere (1982-1983): "El romance Él reguñir, yo regañar en el Auto de la Sibila Casandra", Revista Lusitana, Nova Série, №. 3, pp. 55-67.

Ferré, Pere (2000-2004): Romanceiro Português de Tradição Oral Moderna Portuguesa. Versões Editadas (1828-1960), 4 vols., Lisboa, Fundação Calouste Gulbenkian.

Ferré, Pere (2003): "Breves notas sobre el teatro de Anrique da Mota y Gil Vicente", in Maria Leonor Machado de Sousa et alii (org.), Em Louvor da Linguagem. Homenagem a Maria Leonor Carvalhão Buesco, Lisboa, Colibri, pp. 97-109. 
Frenk, Margit (1982): "«Lectores y oidores». La difusión oral de la literatura en el Siglo de Oro", in Actas del Séptimo Congreso de la Asociación Internacional de Hispanistas, I, Roma, Bulzoni Editore, pp. 101-123.

Frenk, Margit (1997): Lírica española de tipo popular. Edad Media y Renacimiento, 11a. ed., Madrid, Cátedra (1a.. ed., México, UNAM, 1966).

Frenk, Margit (2006): “Valoración de la lírica popular en el Siglo de Oro", in Poesía popular hispánica: 44 estudios, México, Fondo de Cultura Económica, pp. 58-96.

Gracián, Baltasar (1669): Agudeza y arte de ingenio en que se explican todos los modos y diferencias de concetos con ejemplares escogidos de todo lo mas bien dicho, así sacro, como humano por Lorenzo Gracian, Amberes, En Casa de Geronymo y luanbaut (1a. edição, Huesca, Por luan Nogues, 1648).

Gutiérrez Estupiñán, R. (1992): “Intertextualidad: teoría, desarrollos, funcionamento", Signa, 3, Madrid, UNED, pp. 139-156.

Huizinga, J. (2004): Homo ludens, São Paulo, Perspectiva (1938).

Jenny, Laurent (1979): “A estratégia da forma”, in Intertextualidades, Coimbra, Livraria Almedina, pp. 5-49.

Martins, Firmino A. (1928/1987): Folclore do Concelho de Vinhais, I, Coimbra, Imprensa da Universidade (reedição facsimilada, Vinhais, Edição da Câmara Municipal.

Melo, Francisco Manuel de (2006): Obras Métricas, edição coordenada por Maria Lucília Gonçalves Pires e José Adriano de Freitas Carvalho, 2 vols., Braga, Edições APPACDM de Braga (1a.. ed., Lyon, Horacio Boessat e George Remeus, 1665).

Melo, Francisco Manuel de (2007): O Fidalgo Aprendiz, ed. crítica, introdução, notas e índice de formas de Evelina Verdelho, A Coruña, Biblioteca-Arquivo Teatral Francisco Pillado Mayor, Departamento de Galego-Portugués, Francés e Lingüística - Universidad da Coruña [in Obras metricas, Lyon, Horacio Boessat e George Remeus, 1665, pp. 238-256].

Michaëlis de Vasconcelos, Carolina (1892): "Romanzenstudien, I. Geschichte einer alten Cidromanze" e "Romanzenstu- dien, II. Quem morre de mal de amores - não se enterra em sagrado", Zeitschrift, XVI, pp. 40-89 e 397-421.

Michaëlis de Vasconcelos, Carolina (1897): "Geschichte der portuguiesischen Literatur", in Grundriss der romanichen Philologie, Hrsg. Von Gustav Gröber, II. Band, 2. Abteilung, Strassburg (Trübner), pp. 129-382.

Michaëlis de Vasconcelos, Carolina (1901): Pedro Andrade de Caminha, Paris, Mocon, Protat Frères.

Michaëlis de Vasconcelos, Carolina (19071909): "Estudos sobre o Romanceiro peninsular: Romances Velhos em Portugal", Cultura Española, V, pp. 767-803, 1021-1057; IX, 1908, pp. 93-132, 435512, 717-758; XIV, pp. 434-483, 697-732 (artigos compilados em Estudos sobre o Romanceiro Peninsular. Romances Velhos em Portugal, 2a ed., Coimbra, Imprensa da Universidade, 1934, reimpresso no Porto, Lelo, 1980).

Michaëlis de Vasconcelos, Carolina (1885): Poesias de Francisco Sá de Miranda, Halle, Niemeyer.

Michaëlis de Vasconcelos, Carolina (18901892): "Estudos sôbre o romanceiro peninsular: Romances velhos em Portugal, Revista Lusitana, II, pp. 156-179 e 193-240.

Morrier, Henri (1981): Dictionnaire de Poétique et de Rhétorique, 3 a . ed., Paris, Press Universitaires de France (1a.. ed., 1969).

Obras de Gil Vicente (1928): Obras de Gil Vicente, reimpressão fac-similada da edição de 1562, Lisboa, Oficinas Gráficas da Biblioteca Nacional.

Pasco, Allan H. (1973): "A Study of Allusion: Barbey's Stendhal in "Le Rideau cramoisy"", Modern Language Association, Vol. 88, No. 3 (May), pp. 461-471.

Pasco, Allan H. (2002): Allusion: a Literary Graft, Toronto, University of Toronto Press (1a.. ed., 1994).

Plett, H. F. (1993): "Intertextualidades”, Criterios, ed. especial, Julio, pp. 65-94.

Pliegos de Praga (1960): Pliegos poéticos españoles en la Universidad de Praga, edición facsímil, 2 vols., Madrid, Joyas Bibliográficas.

Portugal, D. Francisco de (1652): Divinos e Humanos Versos de Dom Francisco de Portugal, Lisboa, Officina Craesbeckiana.
Resende, Garcia de (1990-2003): Cancioneiro Geral de Garcia de Resende, fixação do texto e estudo por Aida Fernandes Dias, 6 vols., Lisboa, Imprensa Nacional - Casa da Moeda (1ª. ed., Cancioneiro geral: cum preuilegio, Lixboa, Hermã de Cãmpos, 1516; versão digital, http:// purl.pt/12096, consultada no dia 9 de Julho de 2010)

Rifaterre, M. (1979): La Prodution du Texte, Paris, Seuil.

Rodríguez Moñino, Antonio (1997): Nuevo diccionario bibliográfico de pliegos sueltos poéticos (Siglo XVI), ed. corregida y actualizada por Arthur L.-F. Askins y Víctor Infantes, Madrid, Castalia.

Rodríguez Moñino, Antonio (1973): Manual bibliográfico de Cancioneros y Romanceros (Siglo XVI), I, Madrid, Castalia.

Senabre, Ricardo (1991): “Poesía y oralidad", Tropelías, 2, pp. 193-202.

Serra, Pedro (2003): "A «máquina de gregos e romanos" e as "nossas velhas", in Conversas Civis. Estudos sobre D. Francisco Manuel de Melo, Salamanca, Luso-Española de Ediciones, pp. 61-71.

Silva de Romances (1970): Silva de romances (Zaragoza, 1550-1551), ed. y estúdio de Antonio Rodríguez Moñino, Zaragoza, Cátedra Zaragoza-Ayuntamiento.

Storck, Wilhelm (1885): Luis de Camoens Sämmtliche, 6 vols., Paderborn, Druck und Verlag von Ferdinand Schöningh.

Tavares Teixeira, J. A. (1906): “Romanceiro transmontano", Revista Lusitana, IX, pp. 277-323.

Vasconcelos, Jorge Ferreira de (1560): Comedia Eufrosina. De novo revista \& em partes acrece[n]tada, Em Coimbra, Por João de Barreyra.

Vasconcelos, Jorge Ferreira de (1618): Comedia Ulysippo de Jorge Ferreira de Vasconcellos, Nesta segunda impressão apurada, \& correcta de algus erros da primeira, Em Lisboa, Na Officina de Pedro Craesbeeck.

Wolf, Ferdinand (1856): Proben portuguiesischer und catalanischer Volksromanzen, Wien, Aus Der Kaiserlich-Koniglichen Hof-Und Staatsdrucherei.

Wolf, Ferdinand e Hofmann, Conrad (1856): Primavera y Flor de Romances, 2 vols., Berlin, A. Asher y Comp. 